https://doi.org/10.31713/m1119

\title{
POSSIBILITIES OF USING ALKALINE EARTH BENTONITE CLAYS OF CHERKASY DEPOSIT IN PELLET PRODUCTION PROCESSES
}

\author{
F.M. Zhuravlev \\ State University of Economics and Technology, Candidate \\ of Technical Science, Associate Professor, Senior Lecturer, Ukraine \\ E.V. Chuprinov \\ State University of Economics and Technology, Candidate \\ of Technical Science, Associate Professor, Senior Lecturer, Ukraine \\ A.K. Tarakanov \\ Ukrainian State University of Science and Technology, Doctor of \\ Technical Science, Professor, Ukraine \\ D.O. Kassim \\ State University of Economics and Technology, \\ Doctor of Technical Science, Professor, Ukraine \\ I.A. Lyakhova \\ State University of Economics and Technology, Candidate \\ of Technical Science, Associate Professor, Senior Lecturer, Ukraine
}

\begin{abstract}
Annotation
Objective: to analyze and determine the potential of alkaline earth bentonite clays of Ukraine for use as a binder in the production of iron ore pellets.

Methods: performing rheological studies of bentonite clay samples and their chemical analysis, electron microscopic studies of samples.

Results: the analysis of the chemical composition and requirements for the rheological characteristics of bentonite clays used in the production of iron ore pellets at metallurgical enterprises of Russia and Ukraine is carried out. The swelling indicators and water absorption of monoionic forms of bentonites of some deposits in water of different hardness are given. The quality of pellets with bentonites, that have a different exchange complex, during an industrial water of various hardness usage is examined. The analysis of the mineralogical and chemical composition, as well as the size and composition of the exchange complex of alkaline-earth bentonite clays of the Cherkasy deposit (Ukraine), which has the largest reserves of such clays in the CIS is carried out. It is shown that clays suitable for the production of pellets are located near the surface of the earth. A comparative analysis of the strength characteristics of pellets using bentonites with an alkaline and alkaline-earth exchange complex is presented.
\end{abstract}


Comparative tests of pelletizing of charges with different humidity and with the addition of $0.5 \%$ alkaline bentonite and a mixture of clays of the IV and II layers of the Cherkasy deposit have been carried out. It is shown that with increasing humidity in granules with both types of binders, the dynamic strength, porosity and temperature of the "impact" of granules increase with a minimum difference in the absolute values of indicators with different binders.

\section{Introduction}

For the efficient smelting of cast iron in blast furnaces, it is necessary to use iron ore raw materials with the highest possible iron content, minimum silica content, high strength characteristics in the cold state and during heating and reduction in the blast furnace [1].

In the pellets production binders are used as hardening additive for pelletizing finely ground iron ore concentrates. Generally accepted in the industrial production of inorganic binder additives are: fired pellets and bentonite clay with an alkali exchange complex (natural or artificially produced), as well as active lime (slaked or hydrated). Sodium carboxymethyl cellulose, peridur, technical lignosulfonate, sulphitealcohol distillery distillate and other compounds have been used as organic binders in recent decades. The amount of bentonite clay in the charge is (by dry weight) $0,5-1,0 \%$, lime $-2-5 \%$. The amount of organic binder additives in the charge is $0,05-0,1 \%$, that is, an order of magnitude lower than bentonitic clay [2].

In the USSR, all pellet factories used alkaline bentonite clay of one large deposit, divided by the border between the Armenian SSR and the Azerbaijan SSR and named, respectively, at the extraction site on each side, Sarygyuhsky and Dash-Salakhlinsky. Due to the collapse of the USSR and conservation of bentonite production at this field, all pelletizing factories switched to soda ash modified alkaline-earth bentonite clays imported from India and Greece.

The purpose and objectives of research is determination of the possibility of using bentonite clays of Cherkasy deposit as a binder in the production of pellets at Ukrainian GOK.

The productive stratum of the Cherkasy deposit of bentonite and palygorskite clays consists of five layers clearly distinguished by macroscopic features (from top to bottom, of which layers II-IV are suitable for the production of pellets). The methods of research is 
rheological studies of bentonite clay samples and their chemical analysis, electron microscopic studies of samples.

\section{Analysis of problem statement}

Alkaline-earth bentonite clays of the II layer of the Cherkasy deposit, Ukraine, in previous years in a limited amount were also modified with soda ash, although using primitive technology, which did not provide them with high quality and, accordingly, demand. In addition, difficulties arose due to the need for mining and processing enterprises to pump highly mineralized water pumped from mines into the internal water cycle.

All clay minerals have a certain cation exchange capacity. This value is an important characteristic of the mineral and indicates the number of exchangeable cations (expressed in mg-equivalents) capable of being replaced by cations of another type per $100 \mathrm{~g}$ of clay. Montmorillonite, the main mineral of bentonite clay, has the highest cation exchange capacity among clay minerals (up to 90-120 $\mathrm{mEq} / 100 \mathrm{~g}$ of dry clay).

According to the composition of the exchange cations, bentonite clays are divided into:

- alkaline, where more than half of the components of the exchange complex are sodium and potassium cations $\left(\mathrm{Na}^{+}+\mathrm{K}^{+}, \mathrm{mEq} / 100 \mathrm{~g}\right.$ clay);

- alkaline-earth (calcium, magnesium, calcium-magnesium and magnesium-calcium), where more than half of the exchange cations belong to calcium and magnesium $\left(\mathrm{Ca}^{++}+\mathrm{Mg}^{++}, \mathrm{mEq} / 100 \mathrm{~g}\right.$ clay) [2].

Moreover, for the production of pellets by rheological characteristics, bentonite clays with an alkaline exchange complex are most suitable (in an aqueous medium of a certain hardness).

By generally accepted methods, all rheological characteristics of bentonite clays clarify itself in distilled water, and the process water at different enterprises has different hardness, amount and composition of dissolved salts.

Studies have shown that increasing water hardness significantly reduces the swelling and water absorption of bentonites with an alkaline exchange complex (table 1) and practically does not affect these indicators in bentonites with an alkaline-earth exchange complex [2]. Moreover, an increase in the hardness of process water, for example, 
Severny GOK (SevGOK) from $8,8 \mathrm{mEq} / \mathrm{dm}^{3}$ in 1979 to 127,6 $\mathrm{mEq} / \mathrm{dm}^{3}$ in 2017 led to a decrease in the swelling of bentonite from 10,2 to 4,3 times, and water absorption - from 344 to $178 \%$. This effect also affected the deterioration of the properties of raw pellets at the same consumption of bentonite in the charge.

Table 1

Swellability and water absorption of monoionic forms of bentonites of different deposits in water of different rigidity

\begin{tabular}{|c|c|c|c|c|}
\hline Material & Type of water & $\begin{array}{l}\text { Water hard- } \\
\text { ness, } \\
\mathrm{mg} \cdot \mathrm{eq} / \mathrm{dm}^{3}\end{array}$ & $\begin{array}{l}\text { Swelling, } \\
\text { once }\end{array}$ & $\begin{array}{l}\text { Water ab- } \\
\text { sorption } \\
\text { (Enslin), \% }\end{array}$ \\
\hline \multirow{4}{*}{ Na-Sarygyuhsky } & Distilled & 0,07 & 13,6 & 371 \\
\hline & $\begin{array}{l}\text { Industrial } \\
\text { SevGOK } * 1\end{array}$ & 8,8 & 10,2 & 344 \\
\hline & $\begin{array}{l}\text { Industrial } \\
\text { SevGOK } * 2\end{array}$ & 127,6 & 4,3 & 178 \\
\hline & Mine & 274,5 & 3,0 & 160 \\
\hline \multirow{3}{*}{ Ca-Sarygyuhsky } & Distilled & 0,07 & 3,4 & 247 \\
\hline & $\begin{array}{l}\text { Industrial } \\
\text { SevGOK } * 1\end{array}$ & 8,8 & 4,8 & 243 \\
\hline & Mine & 274,5 & 3,0 & 208 \\
\hline \multirow{5}{*}{ Na-Cherkasy } & Distilled & 0,07 & 13,2 & 398 \\
\hline & $\begin{array}{l}\text { Industrial } \\
\text { SevGOK } * 1\end{array}$ & 8,8 & 12,5 & 369 \\
\hline & Industrial CGOK & 43,6 & 7,6 & 352 \\
\hline & Industrial InGOK & 29,5 & 7,8 & - \\
\hline & Mine & 274,5 & 4,0 & 214 \\
\hline \multirow{3}{*}{ Ca-Cherkasy } & Distilled & 0,07 & 4,8 & 215 \\
\hline & $\begin{array}{l}\text { Industrial } \\
\text { SevGOK } * 1\end{array}$ & 8,8 & 3,0 & 200 \\
\hline & Mine & 274,5 & 2,4 & 180 \\
\hline \multicolumn{5}{|c|}{$\begin{array}{l}* 1 \text { Technical water } 1979 \\
*^{2} \text { Technical water } 2017\end{array}$} \\
\hline
\end{tabular}

Thus, an increase in the hardness of industrial water at enterprises producing iron ore concentrates worsens the rheological characteristics of alkaline bentonite clays, which are positive for the production of pellets, to the level of alkaline-earth clays and requires their increased consumption, which naturally reduces the iron content in the pellets. 
There are lots of bentonite clay deposits with hundreds of millions tons of raw material reserves in Ukraine and Russia, but they are not used in industry due to the lack of systematic and in-depth studies on their suitability. For example, only recently more in-depth studies of the Tikhmenevskoye field (Sakhalin) has begun, more attention are paid now to the deposits of the Central region [4], Voronezh anteclise [5], Cherkasy and others. Scattered works, devoted to these deposits showed that, for a number of qualitative characteristics, these clays do not fully meet the requirements contained in the technical specifications for bentonite clays for pelletizing factories [2], because these bentonites (table. 2) are alkaline earth, while specifications require Na-montmorillonite to be contained in the bentonite. The last leads to a high swelling of clay and the ratio of the amount of sodium with potassium to the sum of calcium with magnesium and the ratio of sodium oxide to potassium oxide naturally exceeding unity.

This factor was the main reason why some Russian and Ukrainian bentonites were found unsuitable for pelletizing iron ore concentrates. Probably the same factor can explain the lack of relevant research work, which would deeply reveal the relationship between the properties of bentonite and the characteristics of the finished pellet, the possibility of pre-processing clay to bring it to the required conditions.

Thus, the geographical location, favorable mountain and environmental conditions for the extraction of these clays in large quantities and the prospects for the use of pellets in the production process provide reliable grounds for choosing these clays as the most worthy object of research. The most effective method for improving the rheological characteristics of alkaline-earth bentonites is their modification, that is, changing their metabolic complex in alkaline with the least cost [2].

In the composition of the productive stratum, for example, Cherkasy deposit, there are three types of alkaline-earth bentonite clays: II layer, containing mainly $\mathrm{Ca}^{++}$ions and substantially less $\mathrm{Mg}^{++}$in the exchange complex; III layer, consisting of the palygorskite mineral, containing mainly $\mathrm{Mg}^{++}$ions in the exchange complex, is substantially less than $\mathrm{Ca}^{++}$and more than in the II layer of $\mathrm{Na}^{+}$ions; IV 
layer, representing a natural mixture of II and III layers in a ratio of an average of about $1: 1$.

Table 2

Chemical analysis of bentonite clays of some deposits used in pellet production in Russia and Ukraine

\begin{tabular}{|c|c|c|c|c|c|c|c|c|}
\hline \multirow[b]{2}{*}{ Clays deposit } & \multicolumn{8}{|c|}{ The content of oxides, $\%$} \\
\hline & $\mathrm{SiO}_{2}$ & $\mathrm{Al}_{2} \mathrm{O}_{3}$ & $\mathrm{Fe}_{2} \mathrm{O}_{3}$ & $\mathrm{CaO}$ & $\mathrm{MgO}$ & $\mathrm{SO}_{3}$ & $\begin{array}{c}\mathrm{Na}_{2} \mathrm{O}+ \\
+\mathrm{K}_{2} \mathrm{O}\end{array}$ & $\begin{array}{c}\text { Puncture } \\
\text { loss }\end{array}$ \\
\hline $\begin{array}{l}\text { Deposits Milos island } \\
\text { (Greece), activated } * 1\end{array}$ & 55,7 & 18,7 & 3,9 & 3,8 & 3,2 & 1,6 & 2,8 & 7,8 \\
\hline $\begin{array}{l}\text { 10th Khutor (Repub- } \\
\text { lic of Khakassia, } \\
\text { Russia)*1 }\end{array}$ & 59,7 & 18,6 & 3,9 & 2,8 & 2,4 & 0,1 & 2,6 & 8,4 \\
\hline $\begin{array}{l}\text { Zyryanskoye deposit } \\
\text { (Kurgan region, Rus- } \\
\text { sia)*1 }\end{array}$ & 57,4 & 19,4 & 6,0 & 1,8 & 3,0 & 0,1 & 1,8 & 9,4 \\
\hline $\begin{array}{l}\text { Dash-Salahlinskoye, } \\
\text { Sarygyuhskoye } \\
\text { (Azerbaijan, Arme- } \\
\text { nia)*2 }\end{array}$ & 58,6 & 13,4 & 4,7 & 2,1 & 2,3 & 0,3 & 2,7 & 15,3 \\
\hline $\begin{array}{l}\text { Konstantinovskoye } \\
\text { deposit (Ukraine) } * 1\end{array}$ & 52,2 & 16,2 & 8,9 & 5,0 & 2,3 & 0,3 & 2,8 & 9,1 \\
\hline Cherkasy II layer*1 & 58,5 & 17,4 & 6,6 & 1,3 & 1,4 & 0,1 & 0,16 & 7,32 \\
\hline Cherkasy III layer*3 & 55,1 & 17,3 & 6,83 & 0,42 & 7,3 & 0,1 & 1,83 & 10,6 \\
\hline Cherkasy IV layer*1+3 & 55,8 & 17,1 & 6,5 & 3,4 & 5,3 & 0,1 & 1,2 & 7,8 \\
\hline Wyoming (USA)*2 & 64,1 & 14,27 & $\begin{array}{l}\text { No } \\
\text { inf. }\end{array}$ & 1,6 & 2,2 & $\begin{array}{l}\text { No } \\
\text { inf. }\end{array}$ & 4,0 & 9,33 \\
\hline $\begin{array}{l}{ }^{* 1} \text { Alkaline earth. } \\
\text { *2 Alkaline. }^{* 3} \text { Palygorskite. }\end{array}$ & & & & & & & & \\
\hline
\end{tabular}

Palygorskite by structural features is a kind of clay mineral with the ability to high dispersion effect even in environments with a high concentration of electrolytes. In addition, its hydrophilicity exceeds any cation-exchange modification of any clay mineral [6]. These two qualitative characteristics determine the prerequisites for a positive effect in a mixture with alkaline-earth Ca-montmorillonite for the emergence of a stable coagulation dispersed structure, as is created in a dispersion with Na-montmorillonite. Palygorskite and montmorillonite in the IV layer of the Cherkasy deposit makes an even higher quality dispersion both in the sense of colloidal and structuralmechanical properties of the suspension. In addition, the higher dis- 
persion of these two converting minerals than for particles of other layers creates a higher surface area, which is also a favorable factor in the interaction of the particles of the strengthening additive with particles of the concentrate. The location of a large number of water molecules in the zeolite-like channels of the crystalline structure of palygorskite makes this mineral extremely moisture-resistant, supplying water molecules to the system during heating from room temperature to $400-450{ }^{\circ} \mathrm{C}$. Considering that water molecules in crude pellets are the main agent that holds the concentrate particles together, it can be assumed that additives such as palygorskite crystals play a significant role.

The surface of the palygorskite crystals cannot provide high adhesion to the concentrate particles in a dry pellet, but when interacting with montmorillonite particles, this mineral exhibits exceptional structure-forming ability, and alkaline-earth montmorillonite in the presence of palygorskite acquires a higher surface activity, which is successfully implemented in collaboration with the edges of ore minerals.

Another important circumstance is very essential in substantiating the need for introducing finely dispersed palygorskite into the strengthening additive - the presence of magnesium cations in its structure. Palygorskite is inherently a magnesian silicate with a layered tape structure; in the palygorskite of the Cherkasy deposit, a significant part of it is replaced by aluminum. This combination of these two cations is most favorable for the formation of aluminummagnesium spinel layers isostructural with magnetite edges, where magnetite acts as a matrix for the spinel phase. This factor, apparently, plays one of the most significant roles in the hardening of dry pellets when they are heated to $1100{ }^{\circ} \mathrm{C}$.

Thus, the choice of the bentonite and palygorskite clays of the Cherkasy deposit as the object of study was based on sufficiently compelling arguments, although the lack of clearly and comprehensively justified requirements for the quality of raw materials made it difficult to carry out work in terms of using natural forms of clay. 


\section{Thermographic and mineralogical research}

The mineralogical composition of layer I consists of 30-40 \% hydromica, 30-40\% montmorillonite, $20-30 \%$ calcite and it is not suitable for use in the production of pellets.

The mineralogical composition of layer II consists of 95-98 \% Camontmorillonite and 2-5\% quartz. The total distribution area of the layer is $625 \mathrm{~km}^{2}$, the average thickness of the deposit is $6 \mathrm{~m}$, the total clay reserves are about 5,8 billion tons. X-ray diffraction patterns of samples from numerous wells drilled over the entire area of the field give a typical diffraction pattern for montmorillonite (fig. 1).

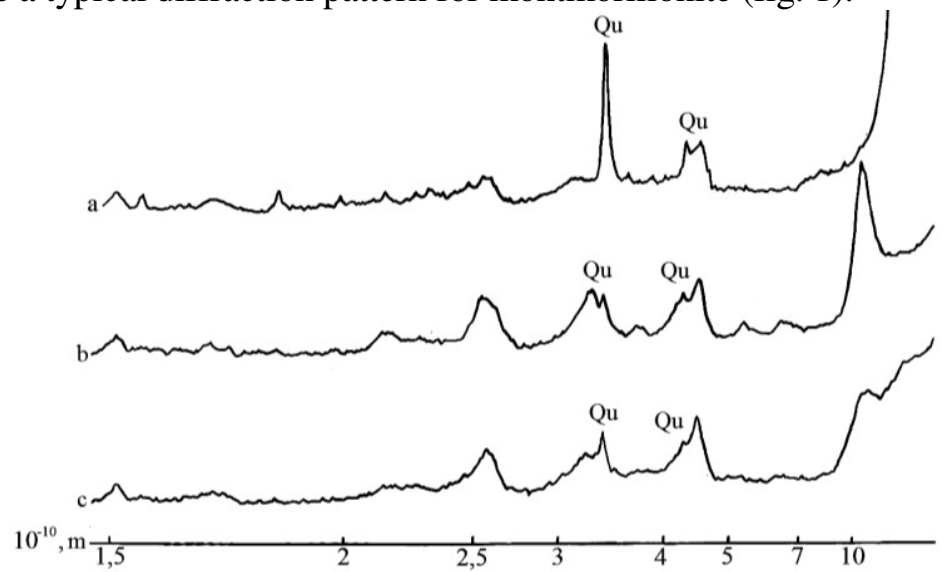

Fig. 1. X-ray diffraction patterns of productive clays the thickness of the Cherkasy deposit: $a$ - II layer (montmorillonite), $b$ - III layer (palygorskite), $c$ - IV layer, Qu - quartz

Thermograms of samples of layer II (fig. 2) have three endothermic effects: a deep endoeffect at $180^{\circ} \mathrm{C}$ with an excess at $250^{\circ} \mathrm{C}$. A weaker endo effect is also observed at $500-600{ }^{\circ} \mathrm{C}$, due to the release of the bulk of hygroscopic water, and the endoeffect caused by the loss of hydroxyl groups at $720-760{ }^{\circ} \mathrm{C}$ due to residues of removal of hydroxyl groups and recrystallization of montmorillonite. The somewhat lower temperature of the second and third endoeffects is caused by the increased iron content in the octahedral positions of the structure of Cherkasy montmorillonite. 


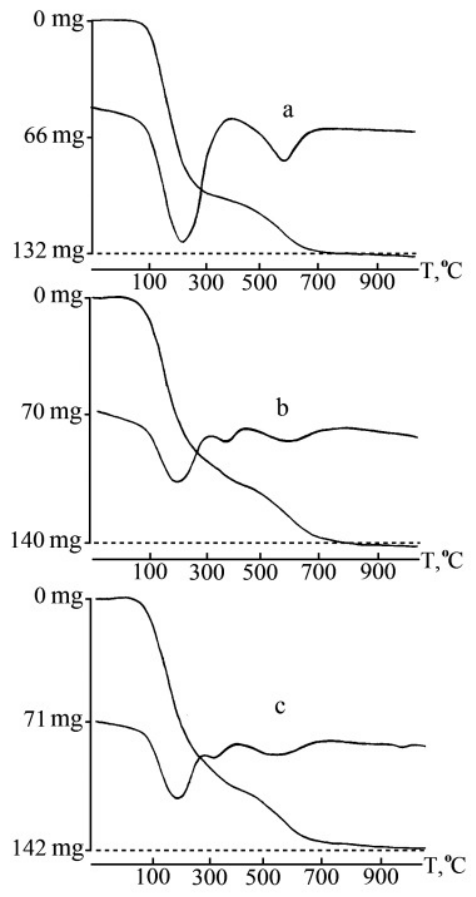

Fig. 2. Thermograms (differential and weight loss curves) of productive clays the thickness of the Cherkasy deposit: $a-$ II layer; $b$ - III layer; $c$ - IV layer

In electron microscopic images (Fig. 3), montmorillonite is represented by small flocculent particles with fuzzy outlines.
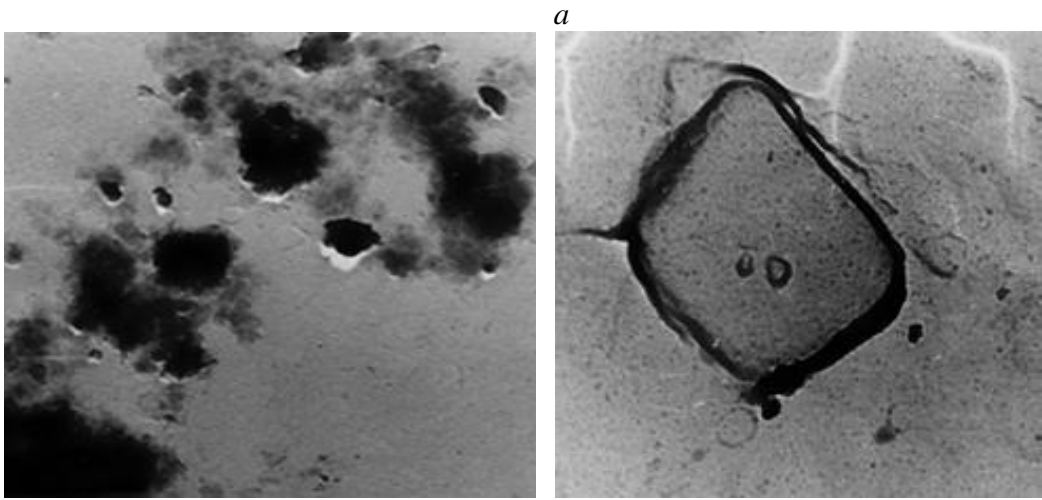

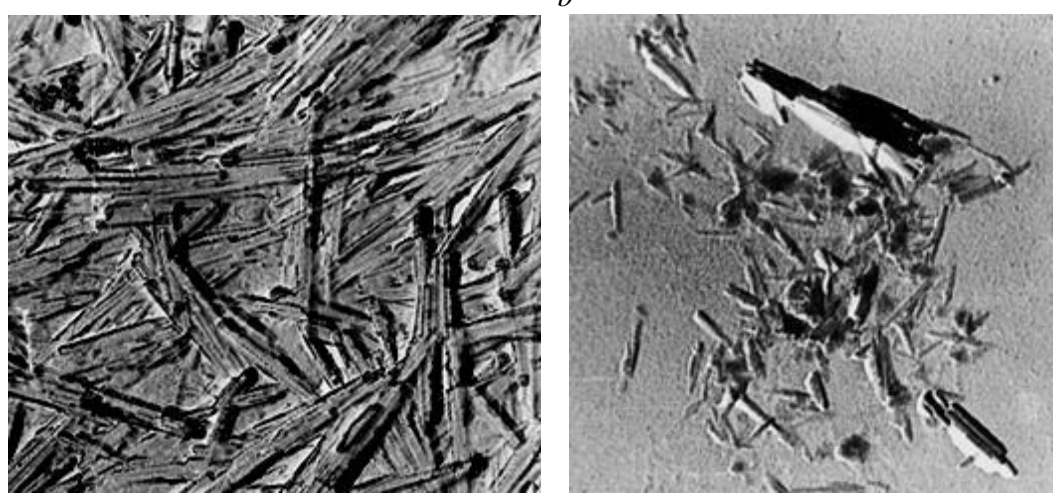

Fig. 3. Electron microscopic images of samples of productive clays the thickness of the Cherkasy deposit: $a-$ II layer (in suspension, in replica); $b-$ III layer (in suspension, in replica)

According to chemical analysis, Cherkasy bentonite is near to the montmorillonites of other deposits presented above (see table 2). Some difference is the increased content of $\mathrm{Fe}^{3+}$, which in Cherkasy bentonite ranges from 5 to $8 \%$. The calculated crystal chemical formula

$$
\mathrm{Na}_{0,03} \mathrm{~K}_{0,03} \mathrm{Ca}_{0,12}\left(\mathrm{Mg}_{0,13} \mathrm{Fe}^{3+}{ }_{0,44} \mathrm{Al}_{1,39}\right)\left[\left(\mathrm{Si}_{3,88} \mathrm{Al}_{0,12}\right)_{4,00} \mathrm{O}_{10}\right](\mathrm{OH})_{2} \cdot 2,6 \mathrm{H}_{2} \mathrm{O}
$$

confirms the montmorillonite composition of clays of the II layer. The deficit of lattice cations is compensated by the exchange cations $\mathrm{Ca}^{2+}, \mathrm{K}^{+}, \mathrm{Na}^{+}$. The total exchange capacity of Cherkasy bentonite is $92,6 \mathrm{mEq} / 100 \mathrm{~g}$ of dry clay.

The III layer consists of four main lenses, separated by erosion of the layer by rivers. The total distribution area of clays of the III layer is $323 \mathrm{~km}^{2}$, the average thickness is $3 \mathrm{~m}$. In the horizontal direction, the quality of clay changes gradually: its sandiness increases to the east. The clay layer is generally uniform; sometimes in the upper part or lower parts of the formation, intercalations of limestone with a thickness of up to $3 \mathrm{~m}$ are observed: in individual wells, the clay is completely replaced by limestone. The total reserves of clay of the III layer are 1195,7 million tons, including 8,4 million tons in the Dashukovsky area.

Clay of the III layer is 96-98\% composed of particles less than $0,01 \mathrm{~mm}$. The silt part is only $1-2 \%$ of the rock. The main rock- 
forming mineral of the III layer is palygorskite (an analogue of American attapulgite). All diffraction patterns of numerous samples from wells and the Dashukovsky quarry contain reflections characteristic of palygorskite $\left(10,48 \times 10^{-10} \mathrm{~m} ; 3,23 \times 10^{-10} \mathrm{~m}\right.$ and other), which do not change either upon heating to $300{ }^{\circ} \mathrm{C}$ or upon processing of samples with organic substances with polar molecules.

The heating curves of Cherkasy palygorskite (see fig. 2, b) have two low-temperature maxima caused by the removal of hygroscopic $\left(180{ }^{\circ} \mathrm{C}\right)$ and zeolite $\left(320{ }^{\circ} \mathrm{C}\right)$ water. The medium temperature endoeffect $\left(560{ }^{\circ} \mathrm{C}\right)$ is due to the formation of a compressed form of palygorskite-II, and the endoeffect at $720-760{ }^{\circ} \mathrm{C}$ is caused by recrystallization of it into enstatite, sillimanite and cristobalite. The electron microsoccopic images of all samples of layer III (see fig. 3, b) clearly show columnar crystals having the form of planks $0,2-0,5$ microns long and 0,02-0,03 microns wide. On the carbon replicas of these samples, it is clearly seen that the individual trims consist of the finest parallel needles [7].

Chemical analysis of clay layer III is given in table. 2. The crystalline formula in terms of layers

$\left[\mathrm{Si}_{8} \mathrm{O}_{20}\right]:\left(\mathrm{Mg}_{1,54} \mathrm{Fe}_{0,83} \mathrm{Al}_{1,49}\right)\left[\left(\mathrm{Si}_{7,43} \mathrm{~K}_{0,22} \mathrm{Ca}_{0,02} \mathrm{Mg}_{0,17} \mathrm{Al}_{0,57}\right)_{8} \mathrm{O}_{20}\right](\mathrm{OH})_{2}$. $\cdot\left(\mathrm{OH}_{3,1} \cdot 4,3 \mathrm{H}_{2} \mathrm{O}\right)$

The total exchange capacity is $27-29 \mathrm{mEq} / 100 \mathrm{~g}$ clay.

The IV layer is distributed in the field with separate lenses, the thickness of which varies from 0,4 to $5,7 \mathrm{~m}$ with an average thickness of $2 \mathrm{~m}$ in the field. The total distribution area of the layer is $344 \mathrm{~km}^{2}$.

Radiographs of clay samples of layer IV of the Cherkasy deposit (see fig. 1, c) contain reflections of montmorillonite and palygorskite. Typically, palygorskite is $30 \%$, and montmorillonite is $70 \%$ : in sandy varieties, the content of palygorskite is reduced to $10 \%$. Thermograms (see fig. 2, c) show a deep endothermic effect at 150 $180{ }^{\circ} \mathrm{C}$ due to the removal of adsorption water and endo effects at 600 and $740-760{ }^{\circ} \mathrm{C}$, reflecting the removal of $\mathrm{OH}$ groups and the recrystallization of montmorillonite.

Under an electron microscope, fibrous crystals of palygorskite and flake-like flakes of montmorillonite are visible (fig. 4). Palygorskite crystals are characterized by a significantly greater dispersion than in the case of layer III. The heat of wetting of clay of the IV 
layer is $21.2 \mathrm{cal} / \mathrm{g}$, the amount of bound water is $20,9 \%$, and the specific surface is $763 \mathrm{~m}^{2} / \mathrm{g}$.

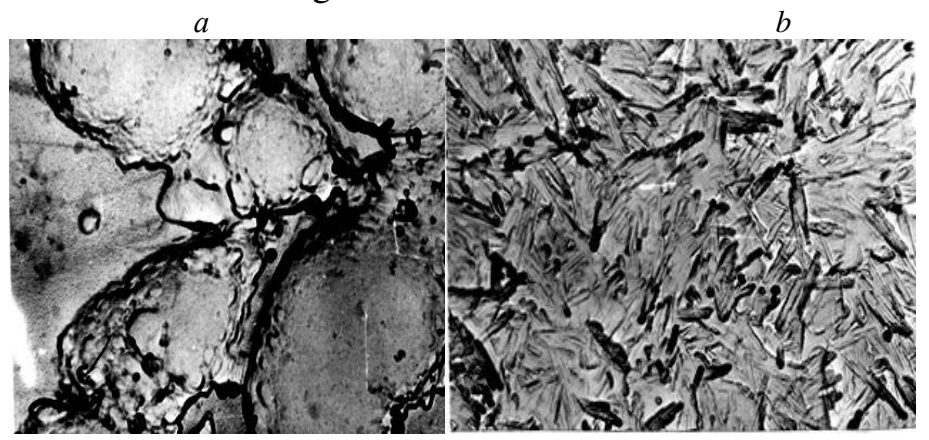

Fig. 4. Electron microscopic images of samples of productive clays the thickness of the Cherkasy deposit: $a$ - IV layer in suspension; $b$ - in replica

The $\mathrm{V}$ layer is represented by lower miocene sands and is not suitable for use as a binder.

The requirements for the quality of bentonite raw materials consumed for pelletizing iron ore pellets should be formulated on the basis of a study of the required technological characteristics of the pellets obtained by using one or another type of bentonite. In turn, the technological characteristics of the pellets obtained by laboratory methods should be as near as possible to the industrial conditions for the preparation of pellets at different stages of preparation.

According to V.M. Vityugin and P. N. Dokuchaev [8], the increased consumption of bentonite clays under industrial conditions is caused by several reasons, the main one is the extremely uneven distribution of dry finely ground bentonite powder in wet iron ore concentrate due to the ineffective mixing equipment used, which leads to an increase in clay consumption to achieve the necessary quality characteristics of the finished pellet. For example, the authors cite information that in the American practice of pelletizing iron ore concentrates with a moisture content of not more than $10 \%$, the theoretical consumption of high-quality bentonite should be $0,25 \%$, but in fact due to insufficient mixing efficiency, this amount doubles (i.e., 0,5 and $0,8 \%$ or even $1 \%$ ).

Various methods have been developed for using bentonite clays in the process of pelletizing, including: applying alkaline bentonite to 
the surface layer of pellets, preliminary mixing alkaline-earth bentonite with $7 \%$ soda ash, the use of mixed clay compositions with a small amount of high-quality bentonite, etc. These measures can reduce the percentage of bentonite additives and increase the strength of the pellets. Nevertheless, not only the chemical composition of the binder has an effect on the formation of the corresponding binder during high-temperature firing, but also the size and composition of the cation exchange complex, which determine the quality of the raw and calcined pellets.

Thus, it becomes quite obvious that the strength characteristics of the pellets depend not only on the colloidal characteristics of the clay, but also on a number of other indicators, among which the mineralogical and chemical compositions of bentonite clay, the composition and capacity of the exchange complex, the humidity of the concentrate, the rigidity of its process water, and the physical characteristics of the iron ore concentrate are significant.

From the long-term practice of using bentonite clays of different quality in the production of iron ore pellets, requirements have been formed for the rheological characteristics of bentonite (table 3) to ensure the properties of raw and calcined pellets with this binder required by the technology (table 4), and the maximum productivity of their calcining units.

Table 3

Requirements for rheological characteristics of the bentonite clays used in the production of pellet

\begin{tabular}{l|c}
\hline \multicolumn{1}{c|}{ The main clay mineral } & Montmorillonite \\
\hline Alkalinity coefficient in the exchange complex ${ }^{* 1}$ & More than 1,0 at $\mathrm{Na}^{+}>\mathrm{K}^{+}$ \\
\hline Swelling amount ${ }^{* 2}$, once & More than 12,0 \\
\hline Colloid $* 2, \%$ & $90-100$ \\
\hline Water absorption $(\text { Enslin })^{* 2}, \%$ & More than 250 \\
\hline The dynamic viscosity of the suspension $* 2, \mathrm{MPa} \cdot \mathrm{s}$ & More than 9,0 \\
\hline Heat limit without changing physical properties, ${ }^{\circ} \mathrm{C}$ & More than 200 \\
\hline Hydrogen ion concentration $(\mathrm{pH})$ & More than 9,0 \\
\hline Total specific surface, $\mathrm{m}^{2} / \mathrm{kg}$ & More than 35000 \\
\hline$* 1\left(\mathrm{Na}^{+}+\mathrm{K}^{+}\right) /\left(\mathrm{Ca}^{++}+\mathrm{Mg}^{++}\right)$. & \\
$* 2$ By standard techniques, rheological characteristics are determined in distilled \\
water.
\end{tabular}


Table 4

Technological requirements for the properties of raw pellets with qualitative alkaline bentonite

\begin{tabular}{c|c|c|c|c}
\hline $\begin{array}{c}\text { Compressive } \\
\text { strength*1, } \\
\mathrm{kg} / \mathrm{pellet}\end{array}$ & $\begin{array}{c}\text { Compressive } \\
\text { strength of the } \\
\text { dried*1, } \\
\mathrm{kg} / \mathrm{pellet}\end{array}$ & $\begin{array}{c}\text { Impact strength } \\
\text { of the raw } * 2, \\
\text { once }\end{array}$ & $\begin{array}{c}\text { Drying tempera- } \\
\text { ture limit } \\
\text { ("shock")*3, }\end{array}$ & $\begin{array}{l}\text { Content } \mathrm{C} \\
\text { valid } \\
\text { mm) class, \% }\end{array}$ \\
\hline $0,8-1,2$ & More than 3,0 & More than 4,0 & More than 400 & $\begin{array}{c}\text { More than } \\
90,0\end{array}$ \\
\hline
\end{tabular}

*1 Pellets diam. $14 \pm 2 \mathrm{~mm}$.

*2 The number of drops from a height of $500 \mathrm{~mm}$ onto a steel plate before the destruction of pellets diam. $14 \pm 2 \mathrm{~mm}$.

${ }^{* 3}$ It is determined at a coolant filtration rate of $1,2 \mathrm{~nm}^{3} /\left(\mathrm{m}^{2} \cdot \mathrm{s}\right)$.

As additional characteristics for montmorillonite, thermographic and $\mathrm{x}$-ray data are accepted: interval of the second endothermic effect on the thermogram $650-750{ }^{\circ} \mathrm{C}$, the value of the first basal reflection in the $\mathrm{x}$ ray for an air-dry sample $-(12-13) \times 10^{-10} \mathrm{~m}$, although it is undoubted that all of the indicated parameters of clay characteristics are largely arbitrary, since there are cases when "substandard" hardening additives create satisfactory strength characteristics of the finished pellets.

\section{Results of semi-industrial research}

Continuing the research, we conducted laboratory tests to determine the suitability of bentonite clays of different mineralogical composition and ion exchange complex for the production of pellets. Pellets with a diameter of $12-13 \mathrm{~mm}$ were obtained on a laboratory granulator with continuous operation. The preparation of charge materials was as follows: the averaged sample of bentonite clay was dried at a temperature of $105-110{ }^{\circ} \mathrm{C}$, and then crushed to a grain size of $95 \%$ of class $0,05 \mathrm{~mm}$. The crushed bentonite clay was dosed on a wet concentrate. Mixing a 100-kilogram sample was carried out in a drum mixer with mixing bodies and with a mixing efficiency of more than $95 \%$.

In the process of research, the following was determined: moisture content of pellets, the compressive strength of raw and dry pellets, the number of raw pellets dropped from a height of 0,3 meters on the rubber plate and the temperature of the «shock» at a rate of filtration of the coolant through a layer of raw pellets of $1,2 \mathrm{~nm} / \mathrm{sec}$.

The consumption of bentonite pelletizing powder is usually $0,5-0,7 \%$ in dry weight relative to the wet concentrate. In the first series of experiments, a slightly larger $(1 \%)$ consumption of binder was adopted so that 
the influence of the studied clays on the quality indicators of the pellets was revealed more noticeably. In addition to purposively selected samples (by layers), mixtures of samples in various ratios were tested (Table 5), taking into account that when mining in a quarry, the ratio of clays of different varieties can vary widely, and selective excavation and storage can be practically impossible.

Kaolinite was added to some mixtures. The experimental results (Table 5) indicate that, with increased specific consumption of bentonite, the impact resistance (drop) and compressive strength of raw pellets with the addition of Cherkasy Cabentonite are not inferior to the same properties of pellets using alkaline Sarygyuh bentonite as a binder. The strength of raw pellets in all experiments was higher than the prevailing pelletizing requirements in practice (impact strength of 5,6 drops without breaking, the compressive strength of $0,75-0,80$ $\mathrm{kg} /$ pell). The compressive strength of the dried pellets was approximate up to two times the minimum requirements of $2.3-2.5 \mathrm{~kg} /$ pell.

Properties of unfluxed pellets from different concentrates

Table 5 with the addition of alkaline bentonite and clays of the Cherkasy deposit

\begin{tabular}{|c|c|c|c|c|c|c|c|c|}
\hline \multirow{3}{*}{$\begin{array}{l}\text { Name of } \\
\text { additive }\end{array}$} & \multicolumn{4}{|c|}{ Raw pellets properties } & \multicolumn{4}{|c|}{ Burning pellets properties } \\
\hline & \multirow{2}{*}{$\begin{array}{c}\text { Number of } \\
\text { drops, } \\
\text { from } 300 \\
\text { mm/times }\end{array}$} & \multicolumn{2}{|c|}{$\begin{array}{c}\text { Compressive } \\
\text { strength, } \\
\text { kg/pell }\end{array}$} & \multirow{2}{*}{$\begin{array}{c}\text { The tem- } \\
\text { perature of } \\
\text { the } \\
\text { «shock», } \\
{ }^{\circ} \mathrm{C}\end{array}$} & \multirow{2}{*}{$\begin{array}{l}\text { Compressive } \\
\text { strength, } \\
\text { kg/pell }\end{array}$} & \multicolumn{2}{|c|}{ Drum test } & \multirow{2}{*}{$\begin{array}{c}\text { The } \\
\text { degree of } \\
\text { recovery, } \\
\%\end{array}$} \\
\hline & & raw & dry & & & $\begin{array}{c}+5 \\
\mathrm{~mm}\end{array}$ & \begin{tabular}{|l|}
$-0,5$ \\
$\mathrm{~mm}$
\end{tabular} & \\
\hline \multicolumn{9}{|c|}{ CGOK } \\
\hline $\begin{array}{l}\text { Sarygukh } \\
\text { alkaline }\end{array}$ & 8,7 & 1,00 & 5,2 & 575 & 427,4 & 96,0 & 3,8 & 68,60 \\
\hline $\begin{array}{l}\text { IV layer } \\
\text { of } \\
\text { Ch.dep }\end{array}$ & 8,8 & 1,30 & 6,1 & 580 & 382,0 & 95,6 & 4,4 & 67,25 \\
\hline $\begin{array}{l}\text { II layer } \\
\text { of } \\
\text { Ch.dep }\end{array}$ & 12,4 & 1,35 & 6,1 & 540 & 446,6 & 96,1 & 3,9 & 60,90 \\
\hline $\begin{array}{l}\text { III layer } \\
\text { of } \\
\text { Ch.dep }\end{array}$ & 10,7 & 1,38 & 4,3 & 540 & \multicolumn{4}{|c|}{ not carried out } \\
\hline $\begin{array}{l}50 \% \text { IV } \\
\text { layer } \\
+50 \% \\
\text { III layer }\end{array}$ & 16,5 & 1,67 & 5,5 & 510 & 419,6 & 96,0 & 4,0 & 62,10 \\
\hline
\end{tabular}




\begin{tabular}{|c|c|c|c|c|c|c|c|c|}
\hline $\begin{array}{l}50 \% \text { IV } \\
\text { layer } \\
+50 \% \\
\text { kaolinite } \\
\end{array}$ & 8,1 & 1,48 & 5,5 & 530 & - & - & - & - \\
\hline $\begin{array}{l}40 \% \text { IV } \\
\text { layer + } 40 \\
\% \text { II layer } \\
+20 \% \\
\text { kaolinite }\end{array}$ & 14,9 & 1,54 & 6,6 & 540 & 487,6 & 96,2 & 3,7 & 46,80 \\
\hline $\begin{array}{l}80 \% \text { II } \\
\text { layer +20 } \\
\% \text { III } \\
\text { layer }\end{array}$ & 16,5 & 1,20 & 6,4 & 540 & - & - & - & - \\
\hline $\begin{array}{l}50 \% \text { II } \\
\text { layer } \\
+50 \% \\
\text { III layer } \\
\end{array}$ & 14,3 & 1,20 & 5,6 & 530 & - & - & - & - \\
\hline \multicolumn{9}{|c|}{ SevGOK } \\
\hline $\begin{array}{l}\text { Sarygukh } \\
\text { alkaline }\end{array}$ & 12,9 & 1,52 & 6,3 & 470 & - & - & - & - \\
\hline $\begin{array}{l}\text { IV layer } \\
\text { of Ch.dep }\end{array}$ & 18,8 & 1,51 & 5,9 & 490 & - & - & - & - \\
\hline $\begin{array}{l}\text { II layer of } \\
\text { Ch.dep }\end{array}$ & 14,5 & 1,54 & 4,6 & 495 & - & - & - & - \\
\hline \multicolumn{9}{|c|}{ LebGOK } \\
\hline $\begin{array}{l}\text { Sarygukh } \\
\text { alkaline }\end{array}$ & 12,0 & 1,45 & 5,7 & 560 & 455,7 & 97,7 & 2,3 & 60,30 \\
\hline $\begin{array}{l}\text { IV layer } \\
\text { of Ch.dep }\end{array}$ & 11,8 & 1,36 & 5,9 & 580 & 415,0 & 97,5 & 2,5 & 56,30 \\
\hline $\begin{array}{l}\text { II layer of } \\
\text { Ch.dep }\end{array}$ & 11,6 & 1,50 & 5,6 & 520 & 451,5 & 96,9 & 3,1 & 47,20 \\
\hline $\begin{array}{l}50 \% \text { IV } \\
\text { layer } \\
+50 \% \\
\text { III layer } \\
\end{array}$ & 11,5 & 1,70 & 4,9 & 595 & 428,3 & 97,4 & 2,6 & 70,40 \\
\hline $\begin{array}{l}40 \% \text { IV } \\
\text { layer + } 40 \\
\% \text { II layer } \\
+20 \% \\
\text { kaolinite }\end{array}$ & 10,6 & 1,40 & 5,2 & 570 & 528,7 & 97,7 & 2,3 & 47,30 \\
\hline
\end{tabular}

Thus, with the appropriate amount of bentonite powder in the mixture from clays of the Cherkasy deposit, you can get raw pellets of the required quality. When using clays of the IV layer, raw pellets 
from all types of concentrates were characterized on average by the highest values of compressive strength after drying and the temperature of the «shock». In the case of adding to the clay of the IV layer $50 \%$ palygorskite clay of the III layer, the strength of dry pellets from LebGOK and CGOK concentrates decreased, respectively, from 5,9 to $4,9 \mathrm{~kg} /$ pell and 6,1 to $5,5 \mathrm{~kg} /$ pell with stable values of dynamic and static strength of raw pellets.

The addition of only kaolinite $(50 \%)$ to the clay of the IV layer also did not improve the quality of the raw pellets. A favourable combination of the properties of the raw pellets of CGOK (dynamic strength of 14,9 drops, static strength of $1,54 \mathrm{~kg} /$ pell, resistance to compression after drying, $6,6 \mathrm{~kg} /$ pell, the temperature of the «shock» $540{ }^{\circ} \mathrm{C}$ ) was obtained by adding to IV layer $40 \%$ of clays layer II and $20 \%$ kaolinite. For LebGOK concentrate, the average quality values of raw pellets corresponded to the indicated composition of the mixture of bentonite clays. Pellets of good quality were obtained from LebGOK and CGOK concentrates with the addition of $1 \%$ bentonite clay of the II layer. The addition of a small amount of palygorskite to this clay (20\%) does not impair the quality of the pellets from the CGOK concentrate. Pellets of SevGOK with a bundle of clay of the II layer are characterized by reduced compressive strength after drying. The same applies to pellets from the CGOK concentrate using clay only of the III layer.

Table 6

Influence of the quantity of IV layers bentonite clay

of the Cherkasy deposit on the quality of raw pellets from SevGOK concentrate

\begin{tabular}{l|c|c|c|c|c|c}
\hline & \multicolumn{5}{|c}{ Raw pellets properties } \\
\cline { 2 - 5 } $\begin{array}{c}\text { Name of } \\
\text { additive in } \\
\text { charge }\end{array}$ & $\begin{array}{c}\text { The } \\
\text { number } \\
\text { of bun- } \\
\text { dles, } \%\end{array}$ & $\begin{array}{c}\text { Humidity, } \\
\%\end{array}$ & $\begin{array}{c}\text { Compressive } \\
\text { strength, } \\
\mathrm{kg} / \mathrm{pell}\end{array}$ & $\begin{array}{c}\text { The num- } \\
\text { ber of } \\
\text { drops } \\
\text { without } \\
\text { destruction, } \\
\text { times }\end{array}$ & $\begin{array}{c}\text { The tempera- } \\
\text { ture of the } \\
\text { «shock», }{ }^{\circ} \mathrm{C}\end{array}$ \\
\hline $\begin{array}{l}\text { Sarygukh } \\
\text { bentonite }\end{array}$ & 0,5 & 8,4 & 0,97 & 3,5 & 5,0 & 480 \\
\hline $\begin{array}{l}\text { IV layer of } \\
\text { Cherkasy } \\
\text { dep. }\end{array}$ & 0,5 & 8,5 & 1,04 & 3,5 & 5,2 & 550 \\
\hline
\end{tabular}


Influence of the quantity of IV layers bentonite clay

of the Cherkasy deposit on the quality of burning pellets from SevGOK concentrate

\begin{tabular}{l|c|c|c|c|c}
\hline \multirow{2}{*}{$\begin{array}{c}\text { Name of } \\
\text { additive in } \\
\text { charge }\end{array}$} & $\begin{array}{c}\text { Compressive } \\
\text { strength, kg/pell }\end{array}$ & \multicolumn{2}{|c}{ Drum test } & \multicolumn{3}{c}{$\begin{array}{c}\text { The recovery } \\
\text { strength, } \%\end{array}$} \\
\cline { 2 - 6 } & $+5 \mathrm{~mm}$ & $-0,5 \mathrm{~mm}$ & $-0,5 \mathrm{~mm}$ & $+5 \mathrm{~mm}$ \\
\hline $\begin{array}{l}\text { Sarygukh } \\
\text { bentonite }\end{array}$ & 472,7 & 98,1 & 1,9 & 2,8 & 80,35 \\
\hline $\begin{array}{l}\text { IV layer of } \\
\text { Cherkasy dep. }\end{array}$ & 509,2 & 97,9 & 2,0 & 5,75 & 76,6 \\
\hline
\end{tabular}

Thus, the clay variety of the Cherkassk deposit is most favourable for ensuring the good quality of the raw pellets of the Cherkasy deposit, which are a natural mixture of alkaline earth bentonite of the II layer and palygorskite (III layer) in a variable ratio, from 1:1 to 4:1. The high rates of pellets quality were obtained for clay mixtures of layers II and III (in the range of ratios characteristic for layer IV).

For all types of tested binder additives, calcined pellets were characterized by high physical, mechanical and metallurgical properties (Table 5). The effect of the bentonite type on the properties of the finished calcined pellets is not traced. Pellets with the clay of the IV layer of the Cherkassk deposit had the highest temperature of the «shock». It should be noted that the temperature of the "shock" according to experiments to a large extent also depends on the size of the concentrate. So for a thinner concentrate of SevGOK, it was lower by $45-90{ }^{\circ} \mathrm{C}$ in comparison with pellets from CGOK concentrate.

Table 8

Influence of the charges moisture with various binders on the quality indicators of raw pellets with basicity 0,5 of the concentrate of CGOK

\begin{tabular}{l|c|c|c|c|c|c|c}
\hline \multirow{2}{*}{$\begin{array}{c}\text { Name of } \\
\text { additive in } \\
\text { charge }\end{array}$} & $\begin{array}{c}\text { The } \\
\text { number } \\
\text { of bun- } \\
\text { dles, } \%\end{array}$ & $\begin{array}{c}\text { Humidity } \\
\text { of pellets, } \\
\%\end{array}$ & $\begin{array}{c}\text { Compressive } \\
\text { strength, } \\
\mathrm{kg} / \text { pell }\end{array}$ & $\begin{array}{c}\text { The number } \\
\text { of drops } \\
\text { without } \\
\text { destruction, } \\
\text { times }\end{array}$ & $\begin{array}{c}\text { Total } \\
\text { porosity, } \\
\%\end{array}$ & $\begin{array}{c}\text { The tem- } \\
\text { perature of } \\
\text { the } \\
\text { «shock», } \\
{ }^{\circ} \mathrm{C}\end{array}$ \\
\hline $\begin{array}{l}\text { Sarygukh } \\
\text { bentonite }\end{array}$ & 0,5 & 7,7 & 1,26 & 2,9 & 5,6 & 26,31 & 460 \\
\hline Same & 0,5 & 8,7 & 1,08 & 2,55 & 6,3 & 30,04 & 480 \\
\hline Same & 0,5 & 9,65 & 0,65 & 2,35 & 10,6 & 31,50 & 500 \\
\hline $\begin{array}{l}\text { A mix- } \\
\text { ture of }\end{array}$ & 0,5 & 8,0 & 1,04 & 2,7 & 5,2 & 28,28 & 480 \\
\hline
\end{tabular}




\begin{tabular}{l|c|c|c|c|c|c|c}
\hline $\begin{array}{l}\text { clay II } \\
\text { and IV } \\
\text { layers }\end{array}$ & & & & & & & \\
\hline Same & 0,5 & 9,3 & 0,82 & 2,25 & 5,8 & 31,80 & 460 \\
\hline Same & 0,5 & 9,74 & 0,68 & 2,47 & 10,1 & 32,45 & 535 \\
\hline
\end{tabular}

Considering the results of previous studies, further experiments were carried out with bentonites of the IV layer and a mixture of clays of the IV and II layers in a ratio of 1:2. Since clay of the IV layer is a natural mixture of clays of the II and III layers, the addition of clay of the II layer gives a new compositional mixture, which should be considered, also, as a special variety of the IV layer with a high content of alkaline earth bentonite, and as a mixture of clay of the III layer and II layers.

With a consumptions decrease of bentonite from $1 \%$ to $0,5 \%$, the quality indicators of raw pellets decreased to almost the same level, but acceptable for pelletizing for both types of bentonites: Sarygyuhsky and Cherkasy (IV layer) (Table 6, 7, burning temperature $1350{ }^{\circ} \mathrm{C}$, duration $-7 \mathrm{~min}$ ).

Burnt pellets with the addition of Cherkasy bentonite with the same physical and mechanical properties in the cold state showed a slightly greater destructibility during reduction than in experiments with alkaline Sarygyuhsky, although their strength during lowtemperature reduction corresponds to modern requirements: abrasion $5,75 \%$, class output $+5 \mathrm{~mm}-76,7 \%$ (with the required - at least 70 $\%$ ). The increase in bentonite consumption for SevGOK concentrate did not increase the temperature of the «shock».

Under industrial conditions, significant fluctuations in the humidity of the concentrate entering the pelletizing process can take place. In this regard, we conducted comparative experiments with different a moisture content of the mixture before pelletizing, respectively, at a different moisture content of the pellets, with the addition of $0.5 \%$ alkaline and Cherkasy bentonites (a mixture of clays of layers IV and II, Table 8). In both cases, with an increase in humidity, a similar pattern of changes in the properties of pellets is observed for both Sarygyuhsky and Cherkasy bentonites: the dynamic strength increases from 5.6-5.2 to 10.6-10.1 drops, porosity (in Fig. 5-7, the average 
values of three parallel experiments are presented) and the temperature of the "shock" of the pellets (Table 8).

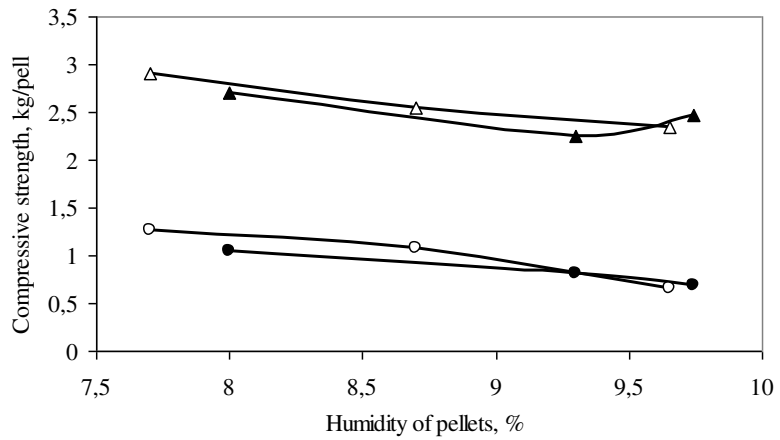

Fig. 5. The effect of humidity of raw pellets on their strength indicators:

$\Delta$ and $\boldsymbol{\Delta}$ are the strength of dry pellets, $\circ$ and $\bullet$ are the strength of raw pellets (with the addition of Sarygyuhsky and Cherkasy bentonite IV layer, respectively)

The temperatures of the "shock" of raw pellets with alkaline earth bentonite at the same humidity are approximately equal to the temperatures with alkaline bentonite. With increasing humidity of the raw pellets, the strength of the raw and dry pellets decreases, and the porosity and drop strength increase. An increase in the moisture of pellets above 9,3\% leads to a decrease in the static strength of the pellets below the minimum permissible limit $(0,75-0,8 \mathrm{~kg} /$ pell $)$ for Cherkasy $(0,68 \mathrm{~kg} /$ pell with $9,74 \%$ humidity of the pellets), and for Sarygukh bentonite $(0,65 \mathrm{~kg} / \mathrm{pell}$ with the pellet moisture content of $9,65 \%)$. At the same time, at relatively high humidity of pellets $9,3 \%$ with Cherkasy bentonite, their strength $(0,82$ $\mathrm{kg} / \mathrm{pell}$ ) is not lower than the minimum limit.

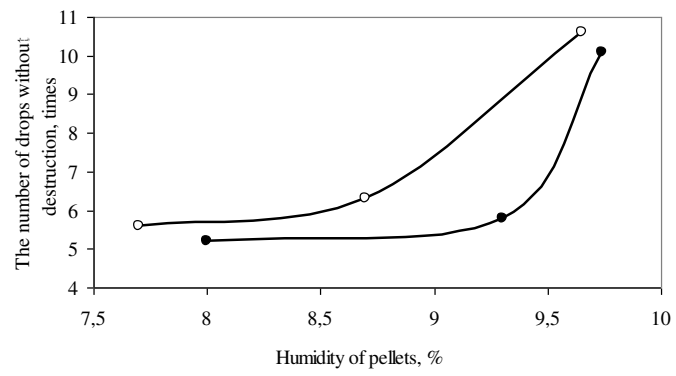

Fig. 6. The effect of humidity of raw pellets on their strength indicators when dropping: $\odot$ and $\bullet-$ with the addition of Sarygyuhsky and Cherkasy bentonite IV layer, respectively 
Graphical analysis of the data given in table 8 and in fig. 5-7 shows that at the same humidity the porosity of raw pellets with Cherkasy bentonite is about $0,8-1 \%$ higher. Graphical analysis of the data given in table 8 and fig. 5-7 shows that at the same humidity the porosity of raw pellets with Cherkasy bentonite is about 0,8-1\% higher. With increasing humidity of the pellets from 7,7-8,0 to 9,7 \%, their porosity increases from 27 to $32 \%$. \%. In this case, the compressive strength of raw and dry pellets with both bentonites is slightly reduced, and the impact strength of raw pellets increases. Thus, according to these tests, when using a mixture of layers IV and II, the quality of raw pellets with Cherkasy bentonite is slightly worse than with Sarygyuhsky, however, the absolute values of the indicators generally satisfy the requirements.

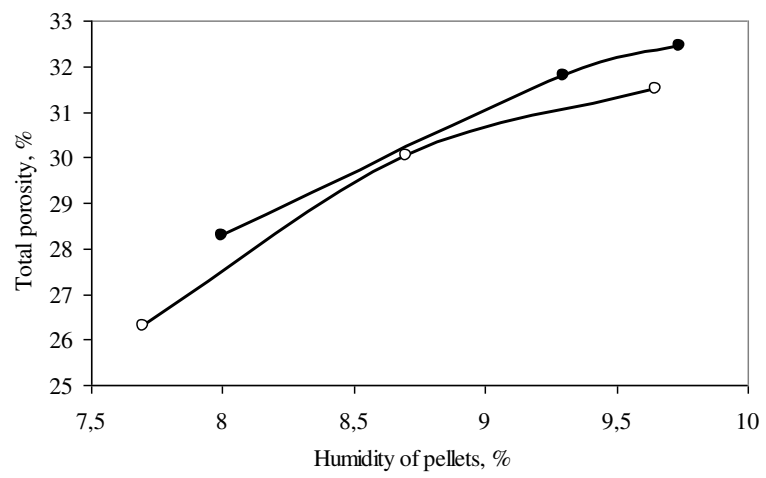

Fig. 7. The effect of humidity of raw pellets on their porosity: $\circ$ and $\bullet-$ with the addition of Sarygyuhsky and Cherkasy bentonite IV layer, respectively

Laboratory tests showed that, despite the relatively lower performance (determined by existing methods in distilled water) of Cherkasy bentonite, pellets from concentrates CGOK, SevGOK and LebGOK obtained with the addition of clays IV, IV and II, III and II layers, are not inferior or inferior insignificantly in properties in the wet and dried state to pellets with the addition of Sarygyukh bentonite.

When using Cherkasy bentonite, it is possible to obtain pellets in approximately the same humidity range of the concentrate as for Sarygyuh bentonite. To objectively confirm the possibility of using alkaline earth bentonite of the Cherkasy deposit (II-III-IV layers) in 
the production of pellets, it is necessary to conduct comparative industrial tests at a pelletizing plant (for example, SevGOK) using a concentrate with increased hardness of industrial water.

\section{Conclusions}

1. Bentonite clay is one of two (bentonite clay and active lime) important inorganic binder additives in the production of iron ore pellets, that provides the required optimal technological parameters of technical units for obtaining high-quality raw pellets and their heat strengthening, to obtain calcined product that meets the requirements of blast furnace smelting.

2. In the production of calcined pellets, it is advisable to use only bentonite clays with an alkalinity coefficient of the exchange complex equal to the ratio $\mathrm{Na}^{+}+\mathrm{K}^{+} / \mathrm{Ca}^{++}+\mathrm{Mg}^{++}>1,0$, wherein $\mathrm{Na}^{+}>\mathrm{K}^{+}$. Moreover, it is desirable that the hardness of the technical water in the concentrate be no more than $10-30 \mathrm{mEq} / \mathrm{dm}^{3}$.

3. An increase in water hardness leads to a partial or complete (depending on the hardness value) replacement of the alkaline exchange complex with an alkaline-earth complex and the conversion of alkaline bentonite clay to alkaline-earth with appropriate rheological characteristics, the deterioration of the lumpiness of the mixture, the characteristics of raw pellets and the need to increase the content of bentonite in the mixture.

4. In the case of increased water hardness in the concentrate, it is economically feasible to use alkaline-earth bentonite clay in the production of pellets, if it is cheaper than alkaline.

5. Palygorskite bentonite clay can be considered as the most promising for the production of iron ore pellets. Long industrial tests should be carried out with its use.

6. The effect of replacing alkaline bentonite in a mixture for the production of pellets with alkaline earth, palygorskite and their mixtures of bentonite clays has been studied. The possibility of using less scarce and expensive local bentonite clays instead of expensive exported alkaline clays without deteriorating the technology is shown by the example of the properties of raw, dry and calcined pellets.

7. The comparative effect of the moisture content of raw pellets on their porosity and strength characteristics with alkaline and alkaline-earth bentonites in the charge was studied. It is shown that the 
absolute values of the indicators with both bentonites at all humidity values correspond to the requirements of the technology, however, the strength when dropping pellets with alkaline earth bentonite is lower than with alkaline.

8. With the studied amounts $(0,5$ and $1,0 \%)$ of bentonites in the charge, the compressive strength of raw and dry pellets with alkaline and Cherkasy bentonite from layer IV (a natural mixture of alkaline earth and palygorskite) was almost the same, and the temperature of the «shock» at second $-20-70{ }^{\circ} \mathrm{C}$ higher.

9. An objective conclusion about the suitability of natural (without modification) Cherkasy bentonite clays and their replacement with alkaline can be determined only as a result of lengthy industrial tests with specific concentrates and industrial water.

\section{References}

1. Lyalyuk, V., Stupnik, N., Zhuravlev, F., Chuprinov, E., Lyakhova, I., Kassim D. (2017). Improving the technology and equipment for the production of iron ore for modern blast furnace smelting. Krivoj Rog: Dionat.

2. Zhuravlev, F., Lyalyuk, V., Stupnik, N., Morkun, V., Chuprinov E., Kassim, D. (2019). Theory, technology and equipment for the production of pellets and new iron ore raw materials for blast furnace. Krivoj Rog: FL-P CHernyavskij D.A.

3. Belousov, P. (2013). Comparative characteristics of high-quality bentonite deposits in Russia and some foreign countries. RUDN Journal of Engineering Researches, № 2, p. 55-61.

4. Demidenok, K., Ladygina, G., Lygach V. (2011). The material composition and technical properties of bentonite-like clays in the Central region of Russia and the assessment of the possibility of improving their quality for use in the most important sectors of modern production. Actual innovative research: science and practice. Tambov State University named G.R. Derzhavin, №4, 10 p.

5. Savko, A. (2014). Clay rocks and minerals associated with them in the Paleozoic and Meso-Cenozoic deposits of the Voronezh anteclise. Article 2. Clay rocks of the Meso-Cenozoic. Proceedings of Voronezh State University. Series: Geology, №1, p. 79-90.

6. Kukovsky, E. (1966). Structural features and physico-chemical properties of minerals. Kiev: Naukova dumka, 1966, 132 p.

7. Kukovsky, E., Ostrovskaya, A. (1962). X-ray analysis of bentont clays of the Dashukovsky site of the Cherkasy deposit of the Ukrainian SSR. Rentgenografiya mineralogicheskogo syr'ya, 1962, vol. 1, $56 \mathrm{p}$.

8. Vityugin, V., Dokuchaev, P. (1986). About the mechanism of action of bentonite additives in the process of pelletizing iron ore charge. M.: Metallurgiya, 1986, $157 \mathrm{p}$. 